\title{
New additions of coccoid green algae to the phycoflora of Brazil and the Neotropics ${ }^{1}$
}

Geraldo José Peixoto Ramos ${ }^{2,4}$, Carlos Eduardo de Mattos Bicudo ${ }^{3}$, Aristóteles Góes-Neto ${ }^{2}$ and Carlos Wallace do Nascimento Moura ${ }^{2}$

Received: 3 July, 2013. Accepted: 3 September, 2013

\begin{abstract}
The present study presents 11 new additions of coccoid green algae to the phycoflora of Brazil, including the first record of the genus Westellopsis for the neotropical region. Samples of periphyton and plankton were collected in two areas of the Marimbus Wetlands (the Marimbus do Baiano and Marimbus do Remanso, within the Marimbus-Iraquara Environmentally Protected Area), in the Chapada Diamantina Region of the state of Bahia, Brazil. Sample collection occurred during dry periods (April-June and August 2011) and rainy periods (October-December 2011 and February 2012). Here, we describe the taxa identified from the 56 samples collected.

Key words: Chlorophyta, Chlorophyceae, Trebouxiophyceae, caatinga, Marimbus Wetlands
\end{abstract}

\section{Introduction}

Coccoid green algae include unicellular taxa without flagella during their vegetative phases, with solitary or colonial habits, covered (or not) by mucilage and growing principally in shallow lentic ecosystems. Their occurrence is influenced by factors such as the illumination regime, temperature, and trophic levels (Komárek \& Fott 1983; Comas 1996; Menezes et al. 2011). Most of the representatives of this group are cosmopolitan, although some are endemic to tropical or temperate regions (Komárek 1983; Komárek \& Jankovská 2001; Coesel \& Krienitz 2008).

Although coccoid green algae have been studied in Brazil since the end of the 19th century (Moseley 1875; Bohlin 1897), it was only in the 1970s that research focusing on these algae became more common, with studies concentrated in the southeast (Sant'Anna 1984; Nogueira 1991, 1994, 1996; Fernandes \& Bicudo 2009; Rosini et al. 2012), south (Felisberto et al. 2001; Moresco \& Bueno 2007; Torgan \& Hentschke 2011; Domingues \& Torgan 2012; Hentschke \& Prado 2012), central-west (De-LamonicaFreire \& Sant'Anna 1993; Nogueira \& Oliveira 2009; Bortolini et al. 2010), and north (Sant'Anna \& Martins 1982; Bittencourt-Oliveira 1993). Little is currently known about these algae in the northeastern region of Brazil, especially in the caatinga (shrublands). The Caatinga Biome, which is the only exclusively Brazilian biome, is characterized by an arid environment with considerable endemic biodiversity
(Mares et al. 1985; Sampaio 1995; Giulietti et al. 2002). Among the major studies focusing on these algae within the Caatinga Biome are those conducted by Ramos et al. (2012) and Ramos (2013).

The present study reports 11 coccoid green algae that represent new records for Brazil, including one new record for the Neotropics, identified from samples collected in the Marimbus Wetlands at the eastern border of the Chapada Diamantina mountain range, a well-defined ecoregion within the Caatinga Biome.

\section{Material and methods}

The Marimbus Wetlands study area is situated on the eastern border of Chapada Diamantina National Park, in the state of Bahia, Brazil. It is a flat, swampy area flooded by the Santo Antônio, Utinga and São José Rivers, which collectively drain a large portion of the region (Lima \& Nolasco 1997; Funch 2002). Due to the rich biodiversity of the local flora and fauna, the swamplands not included in the national park were incorporated into the MarimbusIraquara Environmentally Protected Area by Gubernatorial Decree no. 2216, on June 14, 1993 (Ramos et al. 2012).

The Marimbus Wetlands ( $12^{\circ} 39^{\prime} 13^{\prime \prime}$ to $12^{\circ} 46^{\prime} 48^{\prime \prime} \mathrm{S}$; $41^{\circ} 17^{\prime} 00^{\prime \prime}$ to $41^{\circ} 21^{\prime} 25^{\prime \prime} \mathrm{W}$ ) can be subdivided into four areas (França et al. 2010), all of which are interconnected by the Santo Antônio River (Fig. 1): the Marimbus do Remanso (located in the north, in the municipality of Lençois); the

\footnotetext{
${ }^{1}$ Based on the Master's dissertation of the first author

${ }^{2}$ Universidade Estadual de Feira de Santana, Departamento de Ciências Biológicas, Programa de Pós-Graduação em Botânica, Feira de Santana, BA, Brazil

${ }^{3}$ Instituto de Botânica, Núcleo de Pesquisa em Ecologia, São Paulo, SP, Brazil

${ }^{4}$ Author for correspondence: geraldojpr@gmail.com
} 

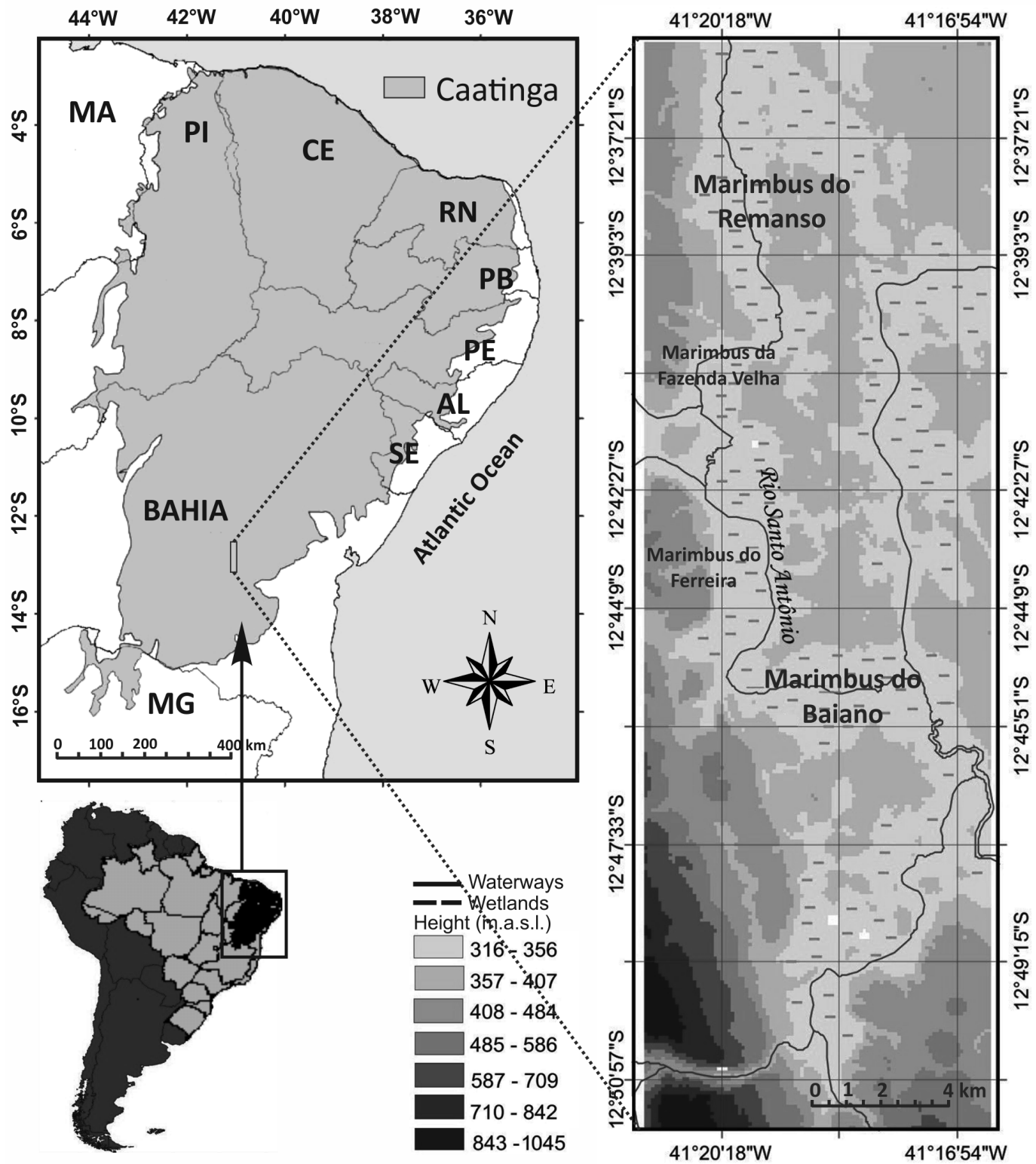

Figure 1. Map of the Marimbus Wetlands area, (Marimbus-Iraquara Environmentally Protected Area), Chapada Diamantina region, state of Bahia, Brazil.

Marimbus da Fazenda Velha; the Marimbus do Ferreira; and the Marimbus do Baiano (the southernmost area, in the municipality of Andaraí).

The regional climate oscillates from subhumid to dry, with an average annual temperature of $22.4^{\circ} \mathrm{C}$, and an average annual rainfall of $1049 \mathrm{~mm}$ (Bahia 2013); maximum water flow occurs from December to March, the lowest flow rates occurring from May through September (Moura \& Marques 2007).

The present study was conducted in two areas of the Marimbus Wetlands (the Marimbus do Remanso and Marimbus do Baiano). The Marimbus do Remanso $\left(41^{\circ} 20^{\prime} \mathrm{W}\right.$; $12^{\circ} 40^{\prime} \mathrm{S}$ ) is located within the municipality of Lençóis, near the village of Remanso, and is characterized by calm waters (in most of its zones), with a $\mathrm{pH}$ 6.6-7.6 and moderate transparency (2.1 m). The Santo Antonio River has a notable influence on the dynamics of the environment, especially in its narrower parts, in which flow rates are higher. The Marimbus do Baiano $\left(41^{\circ} 18^{\prime} \mathrm{W} ; 12^{\circ} 45^{\prime} \mathrm{S}\right)$, located in the municipality of Andaraí, consists of several interconnected lakes, including the Lagoa do Baiano, Lagoa da Isca, Lagoa dos Paus and Olho D'Agua do Peri. Those lakes are most often used by local fishermen during the dry season, when the water level of the Santo Antonio River is well below normal and the lakes are not interconnected. In the present study, most of the samples collected in the Marimbus do Baiano 
were taken from the Lagoa do Baiano. The Marimbus do Baiano is also characterized by calm waters, with a $\mathrm{pH}$ 6.0-7.2 and moderate transparency $(0.9 \mathrm{~m})$. In the Marimbus Wetlands, various macrophytes have been identified (Ramos et al. 2012): Utricularia foliosa L., Cabomba haynesii Wiersema, Eichhornia azurea (Sw.) Kunth., Nymphaea ampla (Salisb.) DC, Salvinia auriculata Aubl. and Hydrocleys nymphoides (Humb. \& Bonpl. ex Willd.).

Phycological material was collected during the dry season (April-June-August/2011) and the rainy season (October-December/2011 and February/2012). From randomly chosen sites within the Marimbus do Baiano and Marimbus do Remanso, we collected a total of 56 samples. The samples of periphytic material were obtained by pressing macrophytes and capturing the planktonic material with a plankton net $(20-\mu \mathrm{m}$ mesh). All collections were made using standard techniques for taxonomic studies of freshwater microalgae (Bicudo \& Menezes 2006).

We measured the physical dimensions of the taxa using an ocular micrometer, and macro photographs were taken with a digital camera coupled to an optical microscope. The taxa were identified based on the specialized literature; the classification system used follows Krienitz \& Bock (2012).

Samples were preserved in Transeau's solution, following Bicudo \& Menezes (2006), and subsequently incorporated into the liquid collection at the Herbarium of the (Bahia) State University of Feira de Santana (code, HUEFS).

\section{Results and discussion}

In the present study, 11 taxa were identified for the first time for Brazil. In addition, we provide the first report of the genus Westellopsis for the Neotropics.

\section{Class: CHLOROPHYCEAE \\ Order: SPHAEROPLEALES \\ Family: SELENASTRACEAE}

Monoraphidium fontinale Hindák, Biol. Práce [Slov. Akad. Vied] 26(6): 144. pl. 60. 1980.

Fig. 2A

Isolated cells, sigmoidal, apices slightly tapering and curved in opposite directions, occupying the same plane; a single chloroplast, parietal, without pyrenoids. Cells 42.5-55 $\mu \mathrm{m}$ long by $2.5-3.7 \mu \mathrm{m}$ wide.

Material examined: BRAZIL. Bahia: Andaraí, Marimbus do Baiano, 01/IV/2011, Moura, C.W.N. \& Ramos, G.J.P. s.n. (HUEFS 178341), 19/VIII/2011, Moura, C.W.N. \& Ramos, G.J.P. s.n. (HUEFS 185348), 10/II/2012, Ramos, G.J.P \& Ribeiro, C.A. s.n. (HUEFS 185414); Lençóis, Marimbus do Remanso, 30/VI/2011, Ramos, G.J.P \& Ribeiro, C.A. s.n. (HUEFS 178390), 20/VIII/2011, Ramos, G.J.P \& Ribeiro, C.A. s.n. (HUEFS 185367).

Habitat: periphyton

Monoraphidium fontinale is similar to M. litorale
Hindák, but differs by having smaller dimensions and straight cells. This species can also be confused with representatives of Chlorobium, although species of the latter genus have evident pyrenoids.

The specimens examined coincided, in terms of their measurements, description and illustrations, with the findings of Komárek \& Fott (1983), although those authors also presented illustrations of individuals with both apices oriented in the same direction. Only individuals with cell apices turned in opposite directions were observed during the present study.

Monoraphidium indicum Hindák, Biol. Práce [Slov. Akad. Vied] 23(4): 105. pl. 44. 1977.

Fig. 2B

Isolated cells, fusiform, strongly arched, apices gradually tapering, occupying distinct planes, a single chloroplast, parietal, without pyrenoids. Cells $75-85 \mu \mathrm{m}$ long by $2.5-3.5$ $\mu \mathrm{m}$ wide.

Material examined: BRAZIL. Bahia: Andaraí, Marimbus do Baiano, 1/IV/2011, Moura, C.W.N. \& Ramos, G.J.P. s.n. (HUEFS 178329); Lençóis, Marimbus do Remanso, 2/IV/2011, Moura, C.W.N. \& Ramos, G.J.P. s.n. (HUEFS 178352), 27/X/2011, Ramos, G.J.P \& Ribeiro, C.A. s.n. (HUEFS 185379).

Habitat: plankton, periphyton

The cells of the specimens collected in the Marimbus Wetlands had dimensions that were smaller than those reported by Komárek \& Fott (1983) and Hindák (1977), although they were otherwise in full agreement with the descriptions and illustrations presented by those authors. According to Hindák (1977), M. indicum differs from other species of the genus by having larger cells, but its distinguishing characteristics, such as sigmoidal cells with apices directed toward distinct planes, are well defined.

According to Bazan et al. (2011), this species is commonly encountered in alkaline waters and is usually associated with aquatic macrophytes.

Monoraphidium obtusum (Korsikov) Komárk.-Legn., Stud. Phyc.: 99. 1969. Ankistrodesmus obtusus Koršikov, Protococcineae: 290. fig. 249. 1953.

Fig. 2C

Isolated cells, cylindrical, fusiform, tapering gradually toward the cell extremities, apices slightly rounded; a single chloroplast, parietal, without pyrenoids. Cells 31.5-35 $\mu \mathrm{m}$ long by 3.7-4.5 $\mu \mathrm{m}$ wide.

Material examined: BRAZIL. Bahia: Andaraí, Marimbus do Baiano, 1/IV/2011, Moura, C.W.N. \& Ramos, G.J.P. s.n. (HUEFS 178342), 29/VI/2011, Ramos, G.J.P \& Ribeiro, C.A. s.n. (HUEFS 178372), 19/VIII/2011, Moura, C.W.N. \& Ramos, G.J.P. s.n. (HUEFS 185352).

Habitat: periphyton

Morphologically, Monoraphidium obtusum can be confused with M. griffithii (Berkeley) Komárk.-Legn., although 
the latter differs by having larger cell dimensions and distinctly tapering apices.

The dimensions of the material collected in the Marimbus Wetlands were slightly smaller than those of the material described by Koršikov (1953, as Ankistrodesmus obtusus), who reported cell dimensions of 40-61 $\mu \mathrm{m}$ long by $4.5-5 \mu \mathrm{m}$ wide. However, the specimens examined coincided with the measurements, illustrations, and descriptions provided by Komárek \& Fott (1983) and Kormáková-Legnerová (1969).

Monoraphidium subclavatum Nygaard, K. Danske Vid. Selsk., Biol. Skr. 21(1): 62. fig. 56. 1977.

Fig. 2D

Isolated cells, lunate, tapering gradually toward the extremities, apices tapering to points; a single chloroplast, parietal, without pyrenoids. Cells 12.5-22.2 $\mu \mathrm{m}$ long by 3.7-5 $\mu$ m wide.

Material examined: BRAZIL. Bahia: Andaraí, Marimbus do Baiano, 19/VIII/2011, Moura, C.W.N. \& Ramos, G.J.P. s.n. (HUEFS 185351), 26/X/2011, Ramos, G.J.P \& Ribeiro, C.A. s.n. (HUEFS 185377), 10/II/2012, Ramos, G.J.P \& Ribeiro, C.A. s.n. (HUEFS 185417); Lençóis, Marimbus do Remanso, 2/IV/2011, Moura, C.W.N. \& Ramos, G.J.P. s.n. (HUEFS 178352), 30/VI/2011, Ramos, G.J.P \& Ribeiro, C.A. s.n. (HUEFS 178389), 20/VIII/2011, Moura, C.W.N. \& Ramos, G.J.P. s.n. (HUEFS 185360), 10/XII/2011, Ramos, G.J.P \& Ribeiro, C.A. s.n. (HUEFS 185398), 11/II/2012, Ramos, G.J.P \& Ribeiro, C.A. s.n. (HUEFS 185420).

Habitat: plankton, periphyton

According to Komárek \& Fott (1983), this species demonstrates considerable phenotypic plasticity, with cells varying from fusiform to lunate or, more rarely, sigmoidal. However, only lunate cells were encountered during the present study.

The principal morphological variations encountered during the present analyses were related to the cell apices, which were sometimes more and sometimes less tapered and pointed.

Morphologically, M. subclavatum is similar to M. caribeum Hindák, although the latter differs by having thinner and more strongly arched cells.

Raphidocelis danubiana (Hindák) Marvan, Komárek \& Comas, Arch. Hydrobiol. Suppl. 67: 386. 1984. Kirchneriella obesa (West) Schmidle var. contorta Schmidle, Flora 78: 44. pl. 7. fig. 2. 1894.

Fig. 2E

Colonial, with 4, 8 or 16 cells arranged irregularly in a single mucilaginous sleeve; cells lunate or horseshoe-shaped, poles rounded; a single chloroplast, parietal, without pyrenoids. Cells 5-6.5 $\mu \mathrm{m}$ long by 1.2-2 $\mu \mathrm{m}$ wide.

Material examined: BRAZIL. Bahia: Andaraí, Marimbus do Baiano, 09/XII/2011, Ramos \& Ribeiro s.n. (HUEFS 185388), 10/II/2012, Ramos \& Ribeiro s.n. (HUEFS 185415).

Habitat: periphyton
Morphologically, the specimens of Raphidocelis danubiana were similar to those of Raphidocelis contorta (Schmidle) Marvan, Komárek \& Comas, although the former differed by having lunate or horseshoe-shaped cells.

The specimens from the Marimbus Wetlands agreed with the descriptions, measurements, and illustrations of Raphidocelis danubiana presented by Komárek \& Fott (1983) and Tsarenko \& John (2011).

Quadrigula closterioides (Bohlin) Printz, Norske Videnskab. Skrift. 2: 4. pl. IV. Fig. 110-116. 1915. Nephrocytium closterioides Bohlin, Bih. K. Svenska Vet.-Akad. Handl. 23 (Afd. III, 7): 18. pl. 1. Fig. 23, 24. 1897.

Fig. 2F-G

Colonial, with 4-16 cells disposed parallel to each other in a sheath of hyaline mucilage; cells fusiform, straight or slightly curved, apices gradually tapering; chloroplast parietal, pyrenoids not seen. Cells 12.5-31.2 $\mu \mathrm{m}$ long by 1.2-2 $\mu$ m wide.

Material examined: BRAZIL. Bahia: Andaraí, Marimbus do Baiano, 29/VI/2011, Ramos, G.J.P \& Ribeiro, C.A. s.n (HUEFS 178372), 19/VIII/2011, Moura, C.W.N. \& Ramos, G.J.P. s.n (HUEFS 185355), 26/X/2011, Ramos, G.J.P \& Ribeiro, C.A. s.n (HUEFS 185369), 09/XII/2011, Ramos, G.J.P \& Ribeiro, C.A. s.n (HUEFS 185392), 10/II/2012, Ramos, G.J.P \& Ribeiro, C.A. s.n (HUEFS 185411).

Habitat: plankton, periphyton

Quadrigula closterioides is similar to Ankistrodesmus falcatus (Corda) Ralfs, although the latter differs by having larger, arched cells. In addition, Q. closterioides has cells that are slightly separated, not tangential.

The specimens collected in the Marimbus Wetlands coincided with the measurements, descriptions, and illustrations presented by Koršikov (1953) and Hindák (1977). According to Tsarenko \& John (2011), this is probably a cosmopolitan species, occurring in the plankton as well as in the periphyton.

\section{Family: SCENEDESMACEAE}

Coelastrum verrucosum (Reinsch) Reinsch, Contrib. Alg. et Fung.: 104. 1875. Sphaerastrum verrucosum Reinsch, Contrib. Alg. et Fung.: 79. Chlorophyllophyceae pl. XIII: fig. 8. 1874.

Fig. 3A-B

Colonies spherical, with 8 or 16 cells united by five processes; cells spherical in lateral and apical views, intercellular spaces small, irregularly shaped; cell wall ornamented with small, free conical outgrowths (verrucae), distributed irregularly; a single chloroplast, parietal, with only one pyrenoid. Dimensions: coenobium 30-36.5 $\mu \mathrm{m}$ diam.; cells 11.5-13.5 $\mu \mathrm{m}$ diam.

Material examined: BRAZIL. Bahia: Andaraí, Marimbus do Baiano, 29/VI/ 2011, Ramos, G.J.P \& Ribeiro, C.A. s.n. (HUEFS 178364), 26/X/2011, Ramos, G.J.P \& Ribeiro, C.A. s.n. (HUEFS 185369), 09/XII/2011, Ramos, G.J.P \& 

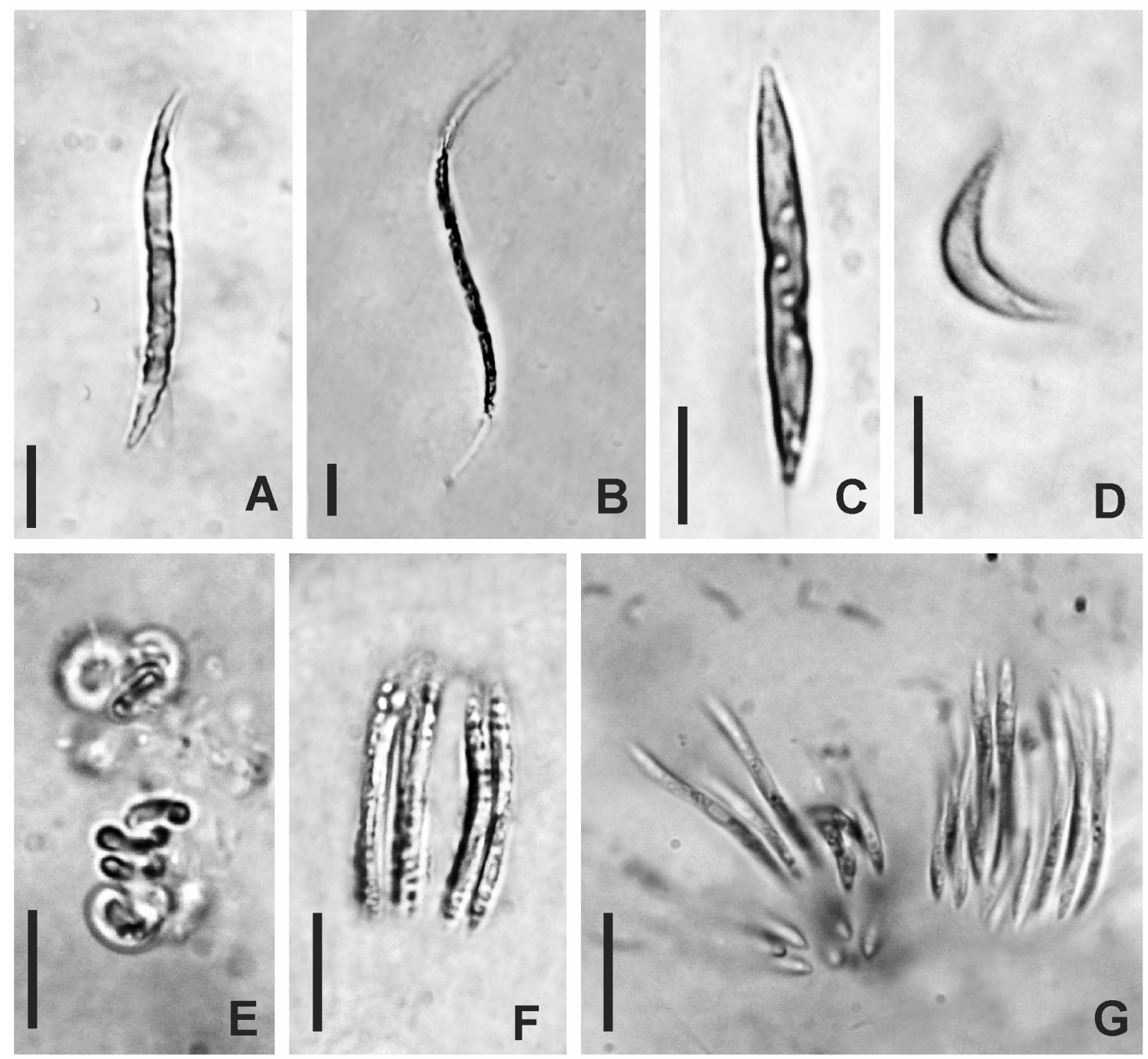

Figure 2. A. Monoraphidium fontinale Hindák; B. M. indicum Hindák; C. M. obtusum (Korsikov) Komárk.-Legn.; D. M. subclavatum Nygaard; E. Raphidocelis danubiana (Hindák) Marvan, Komárek \& Comas; F and G. Quadrigula closterioides (Bohlin) Printz. Bars $=10 \mu \mathrm{m}$.

Ribeiro, C.A. s.n. (HUEFS 185389); Lençóis, Marimbus do Remanso, 10/XII/2011, Ramos, G.J.P \& Ribeiro, C.A. s.n. (HUEFS 185398).

Habitat: plankton, periphyton

Based on cultivation data, Hajdu et al. (1976) classified Coelastrum verrucosum and various other species of Coelastrum (including C. morus West \& G.S.West) as heterotypic (taxonomic) synonyms of C. sphaericum Nägeli, because of their very similar morphologies. Hindák (1992) also undertook a detailed study of C. verrucosum based on cultivation data and demonstrated that this species shows considerable phenotypic plasticity, with spherical, hemispherical, and quadrangular coenobia. However, only spherical coenobia were observed in the material examined here.

The present study followed the considerations of Hindák (1992) and Tsarenko \& John (2011) in recognizing Coelastrum verrucosum as a distinct species, in addition to constituting a currently valid name.
Comas (1996) considered C. morus to be a rare tropical form of $C$. verrucosum, although new records have been made in other countries in the northern hemisphere (Tsarenko \& John 2011) indicating that C. verrucosum is more cosmopolitan than endemic.

Enallax costatus (Schmidle) Pascher, Beih. Bot. Centralbl. 62: 195. 1943. Scenedesmus costatus Schmidle, Österr. Bot. Z. 45: 305. pl. XIV. Fig. 5, 6. 1895.

Fig. 3C

Colonies flat, composed of 4 cells arranged in two alternating rows, without intercellular spaces; cells elliptical to fusiform, cell walls with longitudinal lines; poles with papilliform thickenings; a single chloroplast, parietal, with only one pyrenoid. Cells 16-18 $\mu \mathrm{m}$ long by 2.5-3.5 $\mu \mathrm{m}$ wide.

Material examined: BRAZIL. Bahia: Andaraí, Marimbus do Baiano, 1/IV/ 2011, Moura, C.W.N. \& Ramos, G.J.P. s.n. (HUEFS 178329), 19/VIII/2011, Moura, C.W.N. 
\& Ramos, G.J.P. s.n. (HUEFS 185353); Lençóis, Marimbus do Remanso, 20/VIII/2011, Moura, C.W.N. \& Ramos, G.J.P. s.n. (HUEFS 185365).

Habitat: periphyton

The genus Enallax was proposed by Pascher (1943) based on material collected in the Stubai Alps, southwest of Innsbruck, Austria. The author of that work proposed the species Enallax alpines Pascher and transferred Scenedesmus costatus Schmidle to the new genus as E. costatus (Schmidle) Pascher. Subsequently, Skuja (1964) proposed, in a study of the algae of Laponia, Sweden, E. coelastroides (Bohlin) Skuja from Scenedesmus costatus Schmidle var. coelastroides Bohlin.

Kalina \& Punčochařova (1977) transferred Enallax costatus back to the genus Scenedesmus, based on transmission electron microscope studies showing that the cell wall was composed of two layers, with an internal layer of cellulose and an external layer of sporopollenin.

The presence of intermediary morphotypes between Enallax alpinus, E. coelastroides, and E. costatus allowed Hindák (1990) to unite these three species into just one, $E$. costatus (Schmidle) Pascher.

Up until the 1980s, the genus Enallax appeared to be restricted to Europe (Komárek \& Fott 1983), being found there on humid rocks, in peat bogs, or as planktonic material. Specimens of this genus were later reported from Cuba (Comas 1996), Pakistan (Mehwish \& Aliya 2005), China (Hu \&Wei 2006) and New Zealand (Broady et al. 2012). Comas (1996) believes that the genus has an ample distribution, although it appears to prefer oligotrophic environments.

In Brazil, the genus Enallax was previously restricted to the southeastern state of São Paulo, being represented by E. acutiformis (Schröd.) Hindák (Godinho 2009). This species differs from E. costatus by having rib-like ridges on the cell walls and cell poles that are notably acuminate, similar to spines.

Westellopsis linearis (G.M.Sm.) C.-C. Jao, Acta Hydrobiol. Sin. 1959(4): 394. Figs. 2, 3. 1959. Westella linearis G.M. Sm., Wis. Geol. \& Nat. Hist. Surv. Bull. 57(1): 107. pl. 21. fig. 2-3. 1920.

Fig. 3D-E

Colonies with 8 cells, composed of 2 subcolonies of 4 cells each, united by the inconspicuous remains of the mother-cell wall; cells spherical, subtrapeziform or subtriangular, arranged in the shape of a cross in apical view, and in a slightly curved form in lateral view; a single chloroplast, parietal. Cells 3.5-4 $\mu \mathrm{m}$ diam.

Material examined: BRAZIL. Bahia: Andaraí, Marimbus do Baiano, 29/VI/2011, Ramos, G.J.P \& Ribeiro, C.A. s.n. (HUEFS 178362), 19/VIII/2011, Moura, C.W.N. \& Ramos, G.J.P.s.n. (HUEFS 185350), 26/X/2011, Ramos, G.J.P \& Ribeiro, C.A. s.n. (HUEFS 185374), 09/XII/2011, Ramos, G.J.P \& Ribeiro, C.A. s.n. (HUEFS 185388), 10/II/2012, Ramos, G.J.P \& Ribeiro, C.A. s.n. (HUEFS 185408); Lençóis,
Marimbus do Remanso, 27/X/2011, Ramos, G.J.P \& Ribeiro, C.A. s.n. (HUEFS 185379).

Habitat: periphyton

In terms of its morphology, Westellopsis linearis is similar to Westella botryoides (West) De Wildemann, although the latter differs by having mucilaginous interconnections between the subcolonies.

During the examinations of the material collected in the Marimbus Wetlands, significant morphological variations were observed in terms of the shapes of the cells in the colonies, varying from spherical (when loosely united) to subtriangular or subtrapeziform (when densely packed).

The specimens from the Marimbus Wetlands are in agreement with the descriptions, measurements, and illustrations presented by Komárek \& Fott (1983) and Prescott (1951) for the United States, except in terms of the linear disposition of the cells in the colonies in lateral view.

In addition to the United States, W. linearis has been reported from Asia, Europe, and Oceania (Guiry \& Guiry 2013). This represents the first report of this genus from the Neotropics.

\section{Class: TREBOUXIOPHYCEAE \\ Order: CHLORELLALES \\ Family: CHLORELLACEAE}

Actinastrum gracillimum var. elongatum (G.M.Sm.) Fott, Preslia, 49: 5. 1977. Actinastrum hantzschii Lagerh. var. elongatum G.M. Sm., Öfvers. K. [Svenka] Vet.-Akad. Förh. 39(2): 70. pl. III. figs. 25, 26. 1882.

Fig. 3F

Colonies star-shaped, composed of 4 cells; cells elongated-cylindrical, poles truncated; a single chloroplast, parietal, with only one pyrenoid. Cells $33.5-35 \mu \mathrm{m}$ long by 1.5-2.5 $\mu$ m wide.

Material examined: BRAZIL. Bahia: Andaraí, Marimbus do Baiano, 19/VIII/2011, Moura, C.W.N. \& Ramos, G.J.P. s.n. (HUEFS 185357).

Habitat: plankton

According to Komárek \& Fott (1983), Actinastrum gracillimum var. elongatum differs from the typical variety of that species only in terms of the longer lengths of its cells (30-37 $\mu \mathrm{m})$.

The material collected in the Marimbus Wetlands coincides with the measurements, illustrations, and descriptions provided by Komárek \& Fott (1983), except in terms of the cell width (4-5 $\mu \mathrm{m})$ of the specimens reported from Germany.

This variety was represented by very few collected specimens, and each of the colonies was composed of four cells.

Actinastrum rhaphidioides (Reinsch) Brunnth., Protococcales: 169. fig. 242. 1915. Cerasterias rhaphidioides Reinsch, Algenfl. Franken.: 68. pl. V. fig. 1. 1866.

Fig. 3G 

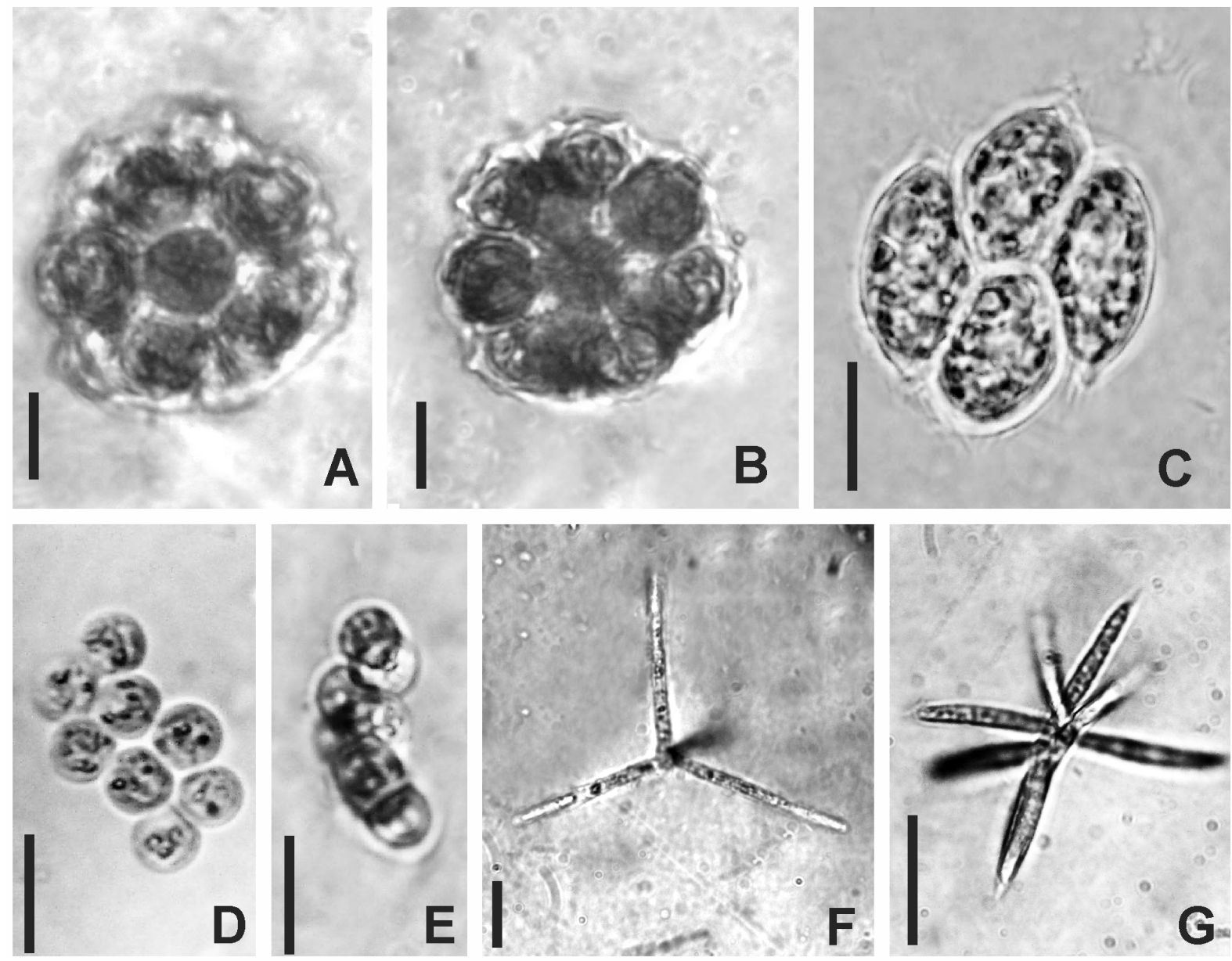

Figure 3. A and B. Coelastrum verrucosum (Reinsch) Reinsch C. Enallax costatus (Schmidle) Pascher; D and E. Westellopsis linearis (G.M.Sm.) C.-C. Jao; E. Side-view detail; F. Actinastrum gracillimum var. elongatum (G.M.Sm.) Fott; G. A. rhaphidioides (Reinsch) Brunnth. Bars $=10 \mu \mathrm{m}$.

Colonies star-shaped, composed of 8 cells; cells elongated-cylindrical to lanceolate, poles tapering; a single chloroplast, parietal, pyrenoids not observed. Cells 18.5-25 $\mu \mathrm{m}$ long by $2.5-3.2 \mu \mathrm{m}$ wide.

Material examined: BRAZIL. Bahia: Andaraí, Marimbus do Baiano, 29/VI/ 2011, Ramos, G.J.P \& Ribeiro, C.A. s.n. (HUEFS 178372), 19/VIII/2011, Moura, C.W.N. \& Ramos, G.J.P. s.n. (HUEFS 185349).

Habitat: periphyton

Morphologically, Actinastrum rhaphidioides is similar to individuals of Actinastrum gracillimum G.M.Sm., although the latter species differs by having cylindrical cells, with truncated poles, as well as proportionally larger cell dimensions.

The material examined from the Marimbus Wetlands coincided with the measurements, illustrations, and descriptions presented by Komárek \& Fott (1983). According to those authors, Actinastrum rhaphidioides is generally found among the plankton populations of small lakes and swampy areas. It is encountered globally in both temperate and tropical regions.
Comparing the occurrence of these taxa between the two areas studied within the Marimbus Wetlands (Marimbus do Baiano and Marimbus do Remanso), we observed that six taxa (Monoraphidium fontinale, M. indicum, $M$. subclavatum, Coelastrum verrucosum, Enallax costatus and Westellopsis linearis) were common between the two areas. However, five taxa occurred exclusively in the Marimbus do Baiano area: M. obtusum, Raphidocelis danubiana, Quadrigula closterioides, Actinastrum gracillimum var. elongatum and A. rhaphidioides. None of the taxa occurred exclusively in the Marimbus do Remanso area.

Regarding habitats, most of taxa occurred within the periphytic community. Only one taxon occurred exclusively within the planktonic community (Actinastrum gracillimum var. elongatum). The main reason for the dominance of periphytic representatives is probably due to the extensive and diverse populations of aquatic macrophytes in the two study areas, especially Utricularia foliosa, Cabomba haynesii, Eichhornia azurea, Nymphaea ampla, and Salvinia auriculata, favoring the establishment and development of several organisms, mostly the periphyton. 
All the 11 taxa identified in the Marimbus Wetlands represent new records for Brazil, expanding the geographic distribution of coccoid green algae to include the Caatinga Biome. This underscores the importance of taxonomic studies of algae in the biome, further studies being necessary in order to increase knowledge of the biodiversity of coccoid green algae in northeastern Brazil.

\section{Acknowledgments}

The authors would like to thank the (Bahia) State University of Feira de Santana and the Botanical Institute of the São Paulo State Department of the Environment, for the logistical support provided, as well as Camila dos Anjos Ribeiro, for assisting in the collection of samples. This study received financial support from the Coordenação de Aperfeiçoamento de Pessoal do Ensino Superior (CAPES, Office for the Advancement of Higher Education; Master's fellowship grant to GJPR), as well as from the Pesquisa Ecológica de Longa Duração (PELD, Long-term Ecological Research) Program, funded by the Brazilian Ministério da Ciência e Tecnologia/Conselho Nacional de Desenvolvimento Científico e Tecnológico (MCT/CNPq, Ministry of Science and Technology/National Council for Scientific and Technological Development; Grant no. 59/2009).

\section{References}

BAHIA. 2013. Superintendência de Estatística e Informações da Bahia - SEI. Available from: http://www.sei.ba.gov.br/ (Accessed: 15 May 2013).

Bazan, G.I.; Alvarez, S.B. \& Martinez de Fabricius, A. L. 2011. Microalgas nuevas para Argentina en sistemas leníticos de la provincia de La Pampa. Biológicas 13(1): 34-43.

Bicudo, C.E.M. \& Menezes, M. 2006. Gêneros de algas de águas continentais do Brasil: chave para identificação e descrições. 2 ed. Editora RiMa.

Bittencourt-Oliveira, M.C. 1993. Ficoflórula do Reservatório de Balbina, Estado do Amazonas, 1: Chlorococcales (Chlorophyceae). Revista Brasileira de Biologia 53(1): 113-129.

Bohlin, K. 1897. Die Algen der ersten Regnell'schen Expedition, 1: Protococcoideen. Bihangtill Svenska Vetenskapsakademie Handlingar 23(7): 3-47.

Bortolini, J.C.; Biolo, S.; Bueno, N.C.; Godinho, L.R. \& Pott, V.J. 2010. Chlorococcales sensu lato (Chlorophyceae) em tanques de depuração de efluente de origem bovina no Mato Grosso do Sul, Brasil. Iheringia: Série Botânica 65(1): 63-74.

Broady, P.A.; Flint, E.A.; Nelson, W.A.; Cassie Coope, V.; De Winton, M.D. \& Novis, P.M. 2012. Phylum Chlorophyta and Charophyta: green algae. Pp. 347-381. In: Gordon, D.P. (Eds). New Zealand inventory of biodiversity 3: Kingdoms Bacteria, Protozoa, Chromista, Plantae, Fungi. Christchurch, Canterbury University Press.

Brunnthaler, J. 1915. Protococcales. Pp. 52-205In: Pascher, A. (Ed.). Die Süsswasserflora von Deutschlands, Österreichs und der Schweiz, Chlorophyceae 2. Jena, Gustav Fischer Verlag.

Coesel, P.F.M. \& Krienitz, L. 2008. Diversity and geographic distribution of desmids and other coccoid green algae. - Biodiversity and Conservation 17(2): 381-392.

Comas, A. 1996. Las Chlorococcales dulciacuícolas de Cuba. Biblioteca Phycologica 99: 1-265.
De-Lamonica-Freire, E.M. \& Sant'Anna, C.L. 1993. Chlorococcales (Chlorophyceae) da Estação Ecológica da Ilha de Taiamã, estado de Mato Grosso, Brasil. Hoehnea 20(1): 107-118.

Domingues, C.D. \& Torgan, L.C. 2012. Chlorophyta de um lago artificial hipereutrófico no sul do Brasil. Iheringia: série Botânica 67(1):75-91.

Felisberto, S.A.; Rodrigues, L. \& Leandrini, J.A. 2001. Chlorococcales registradas na comunidade perifítica no reservatório Corumbá, Estado de Goiás, Brasil, antes e após o represamento das águas. Acta Scientiarum, Biological Sciences 23(2): 275-282.

Fernandes, S. \& Bicudo, C.E.M. 2009. Criptógamos do Parque Estadual das Fontes do Ipiranga, São Paulo, SP. Algas, 25: Chlorophyceae (famílias Chlorococcaceae e Coccomyxaceae). Hoehnea 36(1): 173-191.

Fott, B. 1977. Taxonomische Übersicht der Gattung Actinastrum und der Unterfamilie Actinastroidae (Scenedesmaceae). Preslia 49: 1-8.

França, F.; Melo, E.; Oliveira, I.B.; Reis, A.T.C.C.; Alves, G.L. \& Costa, M.F. 2010. Plantas vasculares das áreas alagadas dos Marimbus, Chapada Diamantina, BA, Brasil. Hoehnea 37(4): 719-730.

Funch, R. 2002. Um guia para a Chapada Diamantina. 3 ed. Cruz da Almas, Nova Civilização.

Godinho, L.R. 2009. Família Scenedesmaceae (Chlorococcales, Chlorophyceae) no Estado de São Paulo: levantamento florístico. $\mathrm{PhD}$ dissertation. Universidade de São Paulo, São Paulo.

Giulietti, A.M.; Harley R.M.; Queiroz, L.P.; Barbosa, M.R.V.; Du BocageNeta, A.L. \& Figueiredo, M.A. 2002. Espécies endêmicas da Caatinga. Pp. 103-118. In: Sampaio, E.V.S.B.; Giulietti, A.M.; Virgínio, J. \& Gamarra-Rojas, C.F.L. (Eds.). Vegetação \& Flora da Caatinga. Recife, Associação Plantas do Nordeste/ Centro Nordestino de Informações sobre Plantas.

Guiry, M.D. \& Guiry, G.M. 2013. AlgaeBase. Galway, World-wide electronic publication, National University of Ireland. Available from: http://www.algaebase.org/ (Accessed: 13 April 2013).

Hajdu L.; Hegewald E. \& Cronberg, G. 1976. Beiträgezur Taxonomie der Gattung Coelastrum/ Chlorophyta, Chlorococcales. Annales Historico Naturales Musei Nationalis Hungarici 68: 31-37.

Hentschke, G.S. \& Prado, J.F. 2012. Chlorococcales s.l. (Chlorophyceae) e Zygnematales (Zygnematophyceae) em um açude do Balneário do Lérmen, Rio Grande do Sul, Brasil. Iheringia: Série Botânica 67(1): 59-74

Hindák, F. 1977. Studies on the chlorococcal algae (Chlorophyceae), 1. Biologické Pracé 23: 1-190.

Hindák, F. 1980. Studies on the chlorococcal algae (Chlorophyceae), 2. Biologické Pracé 26: 1-196.

Hindák, F. 1990. Studies on the chlorococcal algae (Chlorophyceae), 5. Biologické Pracé 36: 1-225.

Hindák, F. 1992. Morphological variation of two species of the chlorococcal genus Coelastrum, C. verrucosum and C. palii. Algological Studies 65: 35-42.

Hu, H. \& Wei, Y. 2006. The freshwater algae of China. Systematics, taxonomy and ecology. Science Press.

Jao, C.-C. 1959. On the systematic position of Dimorphococcus A.Br. and Westella De Wild. Acta Hydrobiologica Sinica 1959(4): 387-398.

Kalina, T. \& Punčochařova, M. 1977. Taxonomy and morphological comparison of three chlorococcal algae: Scotiella oocystiformis Lund., Enallax coelastroides (Bohlin) Skuja and Scenedesmus costatus Schmidle. Algological Studies 19: 105-141.

Komárek, J. \& Fott, B. 1983. Chlorophyceae (grünalgen) Ordnung: Chlorococcales. In: Huber-Pestalozzi, G. (org.). Das Phytoplankton des Süsswassers: Systematic und Biologie. E. Schweizerbart'sche Verlagsbuchhandling (Nägele u. Obermiller). Stuttgart 7(1), 1044.

Komárek, J. \& Jankovská, V. 2001. Review of the green algal genus $P e-$ diastrum; implication for pollenanalytical research. Bibliotheca Phycologica 108: 1-127.

Komárková-Legnerová, J. 1969. The systematics and ontogenesis of the genera Ankistrodesmus Corda and Monoraphidium gen. nov. Pp. 75-122. In: Foot. B. (Ed.). Praha, Studies in Phycology.

Koršikov, O.A. 1953. Pidklas Protokokovi (Protococcineae). Viznačnik prisnovodnich vodorostej Ukrainskoj RSR 5: 1-439.

Krienitz, L. \& C. Bock 2012. Present state of the systematics of planktonic coccoid green algae of inland waters. Hydrobiologia 698(1): 295-326. 
Lima, C.C.U. \& Nolasco, M.C. 1997. Lençóis: uma ponte entre a geologia e o homem. Feira de Santana, Editora da UEFS.

Mares, M.A.; Willig, M.R. \& Lacher Jr., T.E. 1985. The Brazilian caatinga in South American zoogeography: tropical mammals in a dry region. Journal of Biogeography 12: 57-69.

Mehwish, H. \& Aliya, R. 2005. Occurrence of freshwater algae at different localities of Karachi University. International Journal of Phycology and Phycochemistry 1(2): 117-124.

Menezes, V.C.; Bueno, N.C.; Bortolini, J.C. \& Godinho, L.R. 2011. Chlorococcales sensu lato (Chlorophyceae) em um lago artificial urbano, Paraná, Brasil. Iheringia, Série Botânica 66(2): 227-240.

Moresco, C. \& Bueno, N.C. 2007. Scenedesmaceae (Chlorophyceae, Chlorococcales) de um lago artificial urbano: Desmodesmus e Scenedesmus. Acta Scientiarum, Biological Sciences 29(3): 289-296.

Moseley, H.N. 1875. Notes on plants collected at St. Paul's Rocks. Journal of the Linnean Society of Botany 14(77): 354-355.

Moura, F.B.P. \& Marques, J.G.W. 2007. Conhecimento de pescadores tradicionais sobre a dinâmica espaçotemporal de recursos naturais na Chapada Diamantina, Bahia. Biota Neotropica 7(3): 119-126.

Nogueira, I.S. 1991. Chlorococcales sensu lato (Chlorophyceae) do Município do Rio de Janeiro e arredores, Brasil: inventário e considerações taxonômicas. Master's Dissertation. Universidade Federal do Rio de Janeiro, Rio de Janeiro.

Nogueira, I.S. 1994. Flora ficológica da Quinta da Boa Vista, Rio de Janeiro, Brasil: Chlorophyceae (Chlorococcales, sensu lato) em um lago artificial com déficit hídrico. Hoehnea 21(1): 175-198.

Nogueira, I.S. 1996. Botryococcaceae, Radiococcaceae e Oocystaceae (Chlorellales, Chlorophyta) do Município do Rio de Janeiro e arredores, RJ, Brasil. Revista Brasileira de Biologia 56(4): 677-696.

Nogueira, I.S.; Oliveira, J.E. 2009. Chlorococcales e Ulothricales de hábito colonial de quatro lagos artificiais do município de Goiânia, GO. Iheringia, Série Botânica 64(2): 123-143.

Nygaard, G. 1977. "New or interesting plankton algae. With a contribution on their ecology. Det Kongelige Danske Videnskabernes Selskab". Biologiske Skrifter 21(1): 1-107.

Pascher, A. 1943. Alpine Algen. I Neue Protococcalengattungen aus der Uralpen. Beihefte zum Botanischen Centralblatt 62: 175-196.
Prescott, G.W. 1951. Algae of the Western Great Lakes area (exclusive for desmids and diatoms). Cranbrook Institute of Science Bulletin 31, Bloomfield Hills.

Printz, H. 1915. Beiträge zur Kenntnis der Chlorophyceen ind ihrer Verbretung in Norwegen. Det Kongelige Norske Videnskabers Selskabs Skrifter 1915(2): 1-76.

Ramos, G.J.P.; Bicudo, C.E.M.; Góes-Neto, A. \& Moura, C.W.N. 2012 Monoraphidium and Ankistrodesmus (Chlorophyceae, Chlorophyta) from Pantanal dos Marimbus, Chapada Diamantina, Bahia State, Brazil. Hoehnea 39(3): 421-434.

Ramos, G.J.P. 2013. Algas verdes cocóides de duas áreas do Pantanal dos Marimbus (Baiano e Remanso), Chapada Diamantina, Bahia, Brasil. Master's Dissertation. Universidade Estadual de Feira de Santana, Feira de Santana.

Reinsch, P. F. 1878. Contributiones ad Algarum aquae dulcis Promontorii Bonae Spei. Journal of the Linnean Society, Botany 16: 232-238.

Rosini, E.F.; Sant'Anna, C.L. \& Tucci, A. 2012. Chlorococcales (exceto Scenedesmaceae) de pesqueiros da Região Metropolitana de São Paulo, SP, Brasil: levantamento florístico. Hoehnea 39(1): 11-38.

Sampaio, E.V.S.B. 1995. Overview of the Brazilian Caatinga. Pp. 35-63. In: Bullock, S.H.; Mooney, H. \& Medina, E. (Eds.), Seasonally dry tropical forests. Cambridge, Cambridge University Press.

Sant'Anna, C.L. 1984. Chlorococcales (Chlorophyceae) do Estado de São Paulo, Brasil. J. Cramer. (Bibliotheca Phycologica 67).

Sant'Anna, C.L. \& Martins, D.V. 1982. Chlorococcales (Chlorophyceae) dos lagos Cristalino e São Sebastião, Amazonas, Brasil: taxonomia e aspectos limnológicos. Revista Brasileira de Botânica 5: 67-82.

Skuja, H. 1964. Grundzüge der Algenflora und Algenvegetation der Fjeldgegenden um Abisko in Schwedisch-Lappland. Nova Acta Societatis Scientiarum Upsaliensis 16(3): 1-404.

Torgan, L.C.; Hentschke, G.S. 2011. Estrutura da comunidade de Chlorococcales 'sensu lato' (Chlorophyceae) em diferentes hábitats aquáticos e hidroperíodos. Acta Botanica Brasilica 25(1): 83-94.

Tsarenko, P.M.; John, D.M. 2011. Phylum Chlorophyta (Green Algae) Order Sphaeropleales. Pp. 461-465. In: John, D.M.; Whitton, B.A. \& Brook, A.J. (Eds). The Freshwater Algal Flora of the British Isles. 2 Edition. Cambridge, Cambridge University Press. 